\title{
Practicing What We Preach: Transforming the TA Orientation
}

Patricia Armstrong, Peter Felten, Jeffrey Johnston, Allison Pingree Vanderbilt University

Brookfield (1995), Schön (1983), and others articulate the necessity and complexity of being critically reflective in our work. Indeed, the value of critical reflection is inherent to educational development as a field in that we frequently encourage such thinking in our consultations with instructors. But practicing what we preach can be difficult. This chapter reflects on an experiment in the transformation of a teaching assistant orientation, a central event of our teaching center. We not only describe and assess the process of revising this orientation, but we also reflect on the implications of this case for broader programming issues in faculty and teaching assistant development.

\section{Introduction}

Historically and currently, orienting and training new graduate teaching assistants (TAs) has been a fundamental, core offering by teaching centers and TA developers at doctoral institutions (Frantz, Beebe, Horvath, Canales, $\&$ Swee, 2005). For many programs and centers, these events mark the beginning of the academic year and serve as signature events, consuming significant amounts of money, time, and energy.

Our practice as educational developers at Vanderbilt University is no different. Started in 1986 as part of the College of Arts and Science, the Vanderbilt University Center for Teaching has placed a central focus on TAs from its inception. The first Teaching Assistant Orientation (TAO) was offered in the late 1980s. Typically attended by 150-200 new TAs, our orientation has traditionally included both plenary and breakout sessions, sorted by discipline 
and/or teaching duties, as well as additional sessions for international TAs, all spanning a three-day period prior to the beginning of the academic year. In preparation for this event, the staff of the Center for Teaching, which now includes graduate student teaching fellows, participates in a two-week training. In terms both of our labor and the monies budgeted for the event, TAO is far and away the most expensive event in our annual list of programs.

Given this local significance, along with the traditional importance of teaching orientations in the work of educational development as a field, the Center for Teaching professional staff has analyzed our TA orientation over the years in order to make it as effective and efficient as possible. In response to this regular evaluation, Vanderbilt's version of the teaching assistant orientation has changed notably over the past 15 years. But the changes have tended to be logistical rather than paradigmatic in nature. Indeed, even after a decision in 2003 to transform our teaching orientation by structuring it around a conceptual, research-based model, we seem only to have made further adaptations to a model that we fear may not be fully meeting our articulated goals for the orientation.

In this chapter, we will briefly describe the small, incremental changes made in the recent past (1998-2002) to Vanderbilt's Teaching Assistant Orientation, discuss the transformational shift we envisioned in 2003 and implemented for TAO 2004, analyze the successes and failures of the orientation in 2004 that resulted from that shift, and reflect on the implications of that analysis for future practice at the center and for educational developers in general. In so doing, we hope to answer three important questions about faculty/TA development programming: What goals are we hoping to achieve through planning and running specific programs? How do we know if these goals are being met? What do we do if (or when) we determine that these goals are not being met?

For us, the function of asking and answering such questions in a public forum is clear. As consultants, we work with clarity and persistence to encourage instructors to identify learning goals for their students and then design courses, assignments, and activities that will help students reach, if not exceed, those goals. We believe we should apply the same principles of alignment to our work, to inspect the process and results of doing so, and to share this reflection with our colleagues. By doing this, we embody the reflective practitioner (Brookfield, 1995; Schön, 1983), who looks thoughtfully at his or her practice and changes that practice-when warranted-on the basis of that inspection. 


\section{Expansion and Adaptation: Vanderbilt's Teaching Assistant Orientation From 1998 to 2003}

In 1997, Vanderbilt's Board of Trustees expanded the scope of the Center for Teaching to include all nine colleges and schools constituting Vanderbilt University. The scope of our teaching assistant orientation necessarily expanded along with that of the center and so, since 1998, has included sessions for students from all of Vanderbilt's schools in which graduate students routinely teach as part of their education: College of Arts and Science, Peabody College of Education and Human Development, Owen Graduate School of Management, School of Engineering, and the Divinity School.

In the wake of this expansion, the center faced a variety of opportunities and challenges associated with our orientation, many of them specific to Vanderbilt, with others resulting from its status as a research-extensive institution. Table 16.1 details some of these challenges as well as the manner in which the Center for Teaching staff addressed them during the initial phases of expansion from 1998-2003.

Strikingly, many of these changes were driven more by logistical and constituency concerns than by adherence to conceptual and theoretical frameworks. That is, they were shaped more in response to the implied question "What can we do to make people like the event better?" rather than by our learning goals ("What do TAs need to learn in order to be effective teachers?"). Even as we worked through the organization and logistics of our teaching assistant orientation to make it more learner-friendly, we were not necessarily looking at our goals for those learners or determining whether logistical changes might adversely affect our learning goals, let alone questioning at a deep level what our fundamental goals were and investigating whether a campus-wide teaching orientation could even bear the weight of those goals.

\section{Enduring Understandings and How People Learn as Paradigm Shifts for TAO 2004}

After our teaching assistant orientation in 2003 we began to consider another revision to the orientation. Past changes had responded to a variety of institutional needs, but the impetus this time emerged from our own questions about the event's goals and purpose. Wiggins and McTighe's (1998) Understanding by Design prompted our original questions and shaped our approach to rethinking our teaching assistant orientation. Wiggins and 
and/or teaching duties, as well as additional sessions for international TAs, all spanning a three-day period prior to the beginning of the academic year. In preparation for this event, the staff of the Center for Teaching, which now includes graduate student teaching fellows, participates in a two-week training. In terms both of our labor and the monies budgeted for the event, TAO is far and away the most expensive event in our annual list of programs.

Given this local significance, along with the traditional importance of teaching orientations in the work of educational development as a field, the Center for Teaching professional staff has analyzed our TA orientation over the years in order to make it as effective and efficient as possible. In response to this regular evaluation, Vanderbilt's version of the teaching assistant orientation has changed notably over the past 15 years. But the changes have tended to be logistical rather than paradigmatic in nature. Indeed, even after a decision in $\mathbf{2 0 0 3}$ to transform our teaching orientation by structuring it around a conceptual, research-based model, we seem only to have made further adaptations to a model that we fear may not be fully meeting our articulated goals for the orientation.

In this chapter, we will briefly describe the small, incremental changes made in the recent past (1998-2002) to Vanderbilt's Teaching Assistant Orientation, discuss the transformational shift we envisioned in 2003 and implemented for TAO 2004, analyze the successes and failures of the orientation in 2004 that resulted from that shift, and reflect on the implications of that analysis for future practice at the center and for educational developers in general. In so doing, we hope to answer three important questions about faculty/TA development programming: What goals are we hoping to achieve through planning and running specific programs? How do we know if these goals are being met? What do we do if (or when) we determine that these goals are not being met?

For us, the function of asking and answering such questions in a public forum is clear. As consultants, we work with clarity and persistence to encourage instructors to identify learning goals for their students and then design courses, assignments, and activities that will help students reach, if not exceed, those goals. We believe we should apply the same principles of alignment to our work, to inspect the process and results of doing so, and to share this reflection with our colleagues. By doing this, we embody the reflective practitioner (Brookfield, 1995; Schön, 1983), who looks thoughtfully at his or her practice and changes that practice-when warranted-on the basis of that inspection. 


\section{Expansion and Adaptation: Vanderbilt's Teaching Assistant Orientation From 1998 to 2003}

In 1997, Vanderbilt's Board of Trustees expanded the scope of the Center for Teaching to include all nine colleges and schools constituting Vanderbilt University. The scope of our teaching assistant orientation necessarily expanded along with that of the center and so, since 1998, has included sessions for students from all of Vanderbilt's schools in which graduate students routinely teach as part of their education: College of Arts and Science, Peabody College of Education and Human Development, Owen Graduate School of Management, School of Engineering, and the Divinity School.

In the wake of this expansion, the center faced a variety of opportunities and challenges associated with our orientation, many of them specific to Vanderbilt, with others resulting from its status as a research-extensive institution. Table 16.1 details some of these challenges as well as the manner in which the Center for Teaching staff addressed them during the initial phases of expansion from 1998-2003.

Strikingly, many of these changes were driven more by logistical and constituency concerns than by adherence to conceptual and theoretical frameworks. That is, they were shaped more in response to the implied question "What can we do to make people like the event better?" rather than by our learning goals ("What do TAs need to learn in order to be effective teachers?"). Even as we worked through the organization and logistics of our teaching assistant orientation to make it more learner-friendly, we were not necessarily looking at our goals for those learners or determining whether logistical changes might adversely affect our learning goals, let alone questioning at a deep level what our fundamental goals were and investigating whether a campus-wide teaching orientation could even bear the weight of those goals.

\section{Enduring Understandings and How People Learn as Paradigm Shifts for TAO 2004}

After our teaching assistant orientation in 2003 we began to consider another revision to the orientation. Past changes had responded to a variety of institutional needs, but the impetus this time emerged from our own questions about the event's goals and purpose. Wiggins and McTighe's (1998) Understanding by Design prompted our original questions and shaped our approach to rethinking our teaching assistant orientation. Wiggins and 
TABLE 16.1

\section{Challenges Addressed in Organizing TA Orientations (1998-2003)}

\begin{tabular}{|l|l|}
\hline \multicolumn{1}{|c|}{ Challenge } & \multicolumn{1}{|c|}{ Response } \\
\hline $\begin{array}{l}\text { Departments want TAs trained with specific } \\
\text { reference to the discipline and the teaching } \\
\text { duties TAs assume in that discipline. }\end{array}$ & $\begin{array}{l}\text { The Center for Teaching recruits teaching } \\
\text { fellows from a variety of disciplines and } \\
\text { works with them to develop breakout sessions } \\
\text { by discipline and teaching type. }\end{array}$ \\
\hline $\begin{array}{l}\text { The need for teaching fellows from science } \\
\text { and engineering disciplines grows, but the } \\
\text { laboratory research demands in these disci- } \\
\text { plines make it difficult for the Center for } \\
\text { Teaching to recruit from these fields. }\end{array}$ & $\begin{array}{l}\text { The Center for Teaching creates half-time } \\
\text { (academic year) and August-only teaching } \\
\text { fellow positions as a more feasible option for } \\
\text { science and engineering graduate students. }\end{array}$ \\
\hline $\begin{array}{l}\text { The teaching fellows' time and the Center for } \\
\text { Teaching's funds (to pay the fellows) need to } \\
\text { be used efficiently. }\end{array}$ & $\begin{array}{l}\text { The Center for Teaching compresses training } \\
\text { into the two to three weeks immediately prior } \\
\text { to TAO; current fellows are encouraged to use } \\
\text { plans of TAO sessions created by fellows in } \\
\text { previous years. }\end{array}$ \\
\hline $\begin{array}{l}\text { Departments have many other tasks for grad- } \\
\text { uate students in the days before classes begin; } \\
\text { preparation for teaching is often seen as tan- } \\
\text { gential or subservient to coursework and re- } \\
\text { search programs. }\end{array}$ & $\begin{array}{l}\text { The Center for Teaching holds TAO just be- } \\
\text { fore classes begin but varies the date/schedule } \\
\text { configuration over the years to fit department } \\
\text { needs: four half days, two full days, then two } \\
\text { six-hour days. }\end{array}$ \\
$\begin{array}{l}\text { Departments and schools want TAs to be } \\
\text { made aware of policies and resources related } \\
\text { to teaching (e.g., sexual harassment, privacy } \\
\text { of student records, honor code, etc.).At the } \\
\text { same time, TAs find plenary sessions devoted } \\
\text { to these topics unengaging. }\end{array}$ & $\begin{array}{l}\text { To move away from the talking heads } \\
\text { approach, the Center for Teaching shifts } \\
\text { discussion of policies and resources to } \\
\text { breakout sessions. }\end{array}$ \\
$\begin{array}{l}\text { Experienced TAs express an interest in teach- } \\
\text { ing workshops aimed at their level of experi- } \\
\text { ence. }\end{array}$ & $\begin{array}{l}\text { Teaching fellows develop concurrent sessions } \\
\text { to address needs and interests of both first- } \\
\text { time TAs and returning instructors. }\end{array}$ \\
\hline
\end{tabular}

McTighe posit a "backward" approach to course and curricular design, similar to Fink's later "integrated course design" (Fink, 2003). The backward design process begins by identifying desired results, moves next to determining acceptable evidence of the achievement of those results, and concludes with developing plans for concrete learning experiences to enable students to generate evidence of their learning (Wiggins \& McTighe, 1998).

To clarify goals in the first stage of backward design, Wiggins and McTighe suggest sorting priorities into three nested categories. We adapted this approach to create the categories for our teaching assistant orientation goals shown in Figure 16.1. 
FIGURE 16.1

Adaptation of Backward Design to

Teaching Assistant Orientation Goals

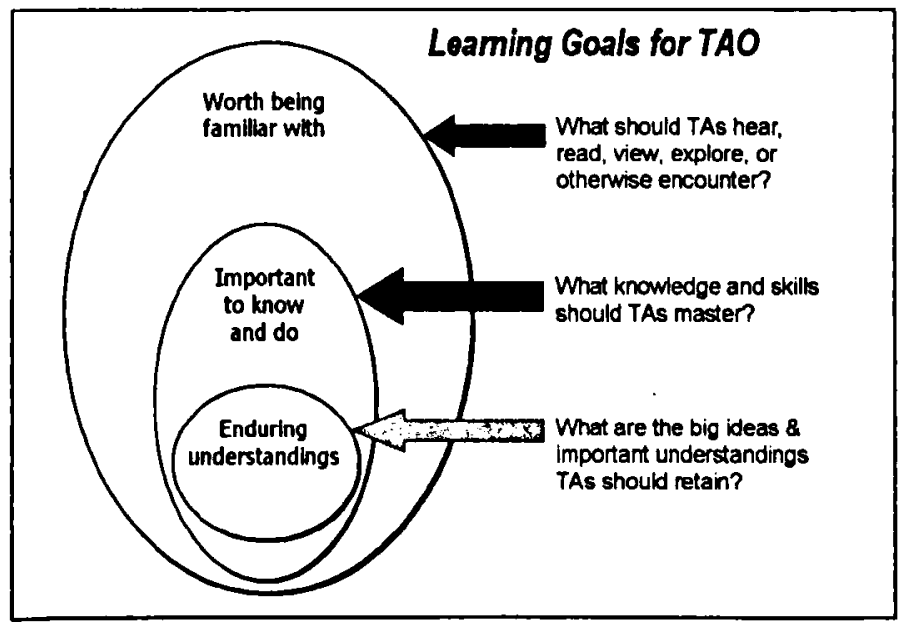

Note Adapted from Wiggins, G., \& McTighe, J. (1998). Understanding by Design. Alexandria, VA: Association for Supervision and Curriculum Development. Reprinted by permission. The Association for Supervision and Curriculum Development is a worldwide community of educators advocating sound policies and sharing best practices to achieve the success of each learner. To learn more, visit ASCD at www.ascd.org. Copyright laws prevent reproduction of this figure without express permission from the Association for Supervision and Curriculum Development.

This categorization helped us see a significant flaw in TAO's basic design. The orientation had evolved over the years to emphasize details that are "worth being familiar with," what Fink (2003) calls the "list of topics" approach (p. 61). It included sessions on institutional policies, grading, holding office hours, and a host of other relevant topics; however, even the Center for Teaching professional staff could not identify our orientation's "enduring understandings" among the mass of details covered. We realized that the orientation seemed to have no unified intellectual or pedagogical core.

In response to that realization, we used a series of brainstorming discussions to articulate four enduring understandings that would serve as the foundation for a reorganized orientation:

- Teaching, like all scholarly activity, is an evolving process of inquiry, experimentation, and reflection.

- The fundamental purpose of teaching is to promote student learning. 
- Understanding how people learn can help one become a more effective teacher.

- Disciplinary differences are significant for both teaching and learning.

To be sure, fragments of these understandings had been present in past versions of our orientation, but none had played a central or shaping role. We wanted to change that in 2004.

As we pondered how we might implement that change, we recalled how the findings in How People Learn-a National Research Council publication tracking "the scientific literatures on cognition, learning, development, culture, and brain" (Bransford, Brown, \& Cocking, 2000, p. 5)-had transformed our own teaching and educational development practice by providing us important insights into the complexities of the learning process. Thus, we decided to use the How People Learn framework as a central conceptual structure to reflect and enact our four enduring understandings for TAO.

The framework, as Figure 16.2 indicates, suggests that effective learning environments comprise four interrelated elements.

\section{FIGURE 16.2}

The How People Learn Framework

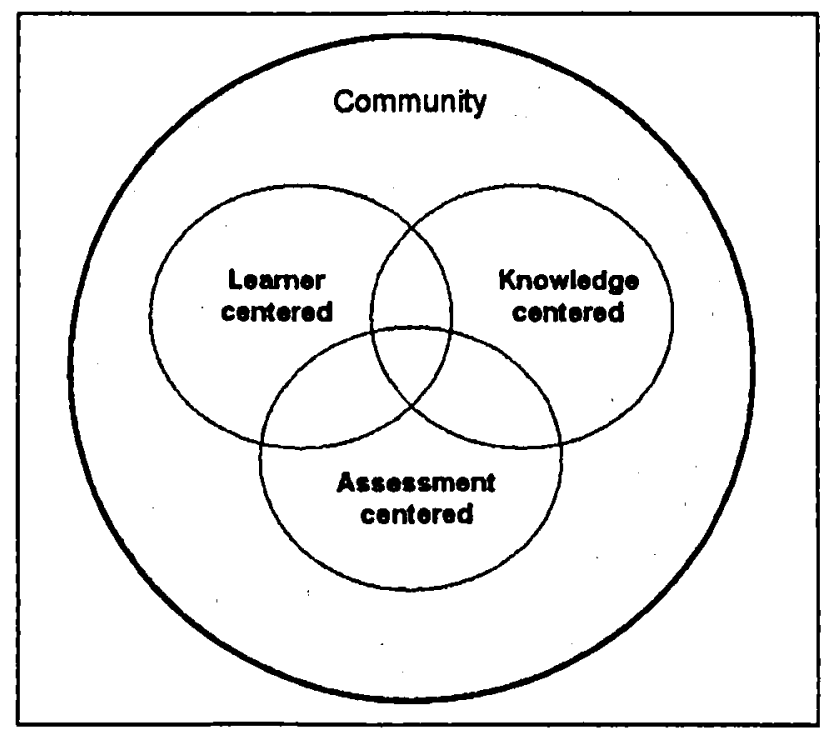

Note. Reprinted with permission from Bransford, Brown, and Cocking, How People Learn: Brain, Mind, Experience, and School (expanded edition). 02000 by the National Academy of Sciences, courtesy of the National Academies Press, Washington, DC. 
- Learner centered environments "pay careful attention to the knowledge, skills, attitudes, and beliefs that learners bring to the educational setting" (Bransford, Brown, \& Cocking, 2000, p. 133). In other words, learner centered environments take into account the distinctive characteristics, abilities, and needs of the students who will be learning.

- Knowledge centered environments focus on the types of information, activities, and reasoning that help students to develop expertise in a particular discipline. Thus, what it means to be knowledge centered will vary from classroom to classroom depending on the structure and purpose of the discipline being learned.

- Assessment centered environments allow frequent opportunities for feedback and revision that directly align with the overall learning goals. Learners need regular opportunities to learn from mistakes and to develop their understanding over time.

- Community centered environments are characterized by "norms for people learning from one another and continually attempting to improve" (Bransford, Brown, \& Cocking, 2000, p. 144). Learning, in short, is a social activity.

Learning might occur in an environment that has any combination of these characteristics, but the authors of How People Learn strongly suggest that deep learning is more likely to occur when these components are in relative balance with one another.

\section{Implementing the Changes in TAO 2004}

For a variety of reasons, including personnel changes at the center and the long planning time required for such a large orientation, we retained the basic two-day structure of our teaching assistant orientation in 2004, even as we revised our core goals. Indeed, in many ways the orientation in 2004 appeared identical to the one held in 2003; we had roughly the same number of participants ( 243 in 2003, and 232 in 2004). The schedule of plenary, cluster, and concurrent sessions remained essentially the same (see Appendices 16.1 and 16.2). Additionally, participants in 2004 were grouped in discipline clusters identical to those used in 2003 (see Appendix 16.3).

Despite these similarities, we were aiming for a truly transformative change in 2004 by establishing our enduring understandings and the How People Learn framework as the foundation for each part of the orientation. 
We introduced this framework during the initial plenary of the orientation, and then structured the disciplinary breakout sessions according to three of the four components of that framework: knowledge centered, learner centered, and assessment centered. While the fourth component, community centered, did not have a dedicated cluster session, we underscored this component by weaving it throughout TAO in two important ways: during the plenary we emphasized how new TAs were entering a community of teachers at Vanderbilt, and in every other orientation session our graduate teaching fellows were explicit about building a sense of community within the session that could be carried on after the session ended. Such changes, we hoped, would keep both us and the TAs focused on learning goals, rather than on logistical adaptations.

\section{Analysis}

We went into TAO 2004 expecting a transformed event. However, when we assessed the orientation after the fact, we began to doubt our achievement. While we emphasized our enduring understandings and the How People Learn framework in the plenary, we did not consistently see major transformations of the disciplinary breakout sessions. But one teaching fellow who facilitated orientation sessions for the second time in 2004 did note a significant change: "I gave the same grading exercise at TAO in 2003 and 2004, but in 2003 it was more about how to grade fairly whereas this time the emphasis was on how we can grade to increase student learning." Despite this instance of transformation, our observation of TAO sessions indicated that more often than not TAO 2004 disciplinary breakouts simply reordered the material covered in 2003. In Table 16.2, we compare the learning goals of the TAO engineering sessions in 2003 and 2004.

This comparison highlights an all too common trend. While familiarity with the How People Learn framework was added to the list of learning goals, further use of the framework was limited mostly to the organization of the content of the sessions. Many sessions still focused more on a "list of topics" "worth being familiar with" than on enduring understanding.

So why did our transformative intentions not manifest themselves more fully and effectively? One factor derives from how we prepared teaching fellows to facilitate orientation sessions. Although the Center for Teaching professional staff planned and implemented the pre-orientation training for our 12 teaching fellows according to the How People Learn framework, we encouraged them to use session outlines and handouts from previous orientations. 
TABLE 16.2

\section{Comparison of Learning Goals for Engineering Sessions in 2003 and 2004}

\begin{tabular}{|c|c|}
\hline $\begin{array}{c}\text { TAO } 2003 \\
\text { Discipline: Engineering }\end{array}$ & $\begin{array}{c}\text { TAO 2004 } \\
\text { Discipline: Engineering }\end{array}$ \\
\hline $\begin{array}{l}\text { Teaching Cluster I-Getting Started: } \\
\text { Expectations and Duties of TAs } \\
\text { Learning Goals } \\
\text { - Get to know other TAs } \\
\text { - Duties of TAs in School of } \\
\text { Engineering departments } \\
\text { - What do students expect from TAs? } \\
\text { - What do professors expect from TAs? }\end{array}$ & $\begin{array}{l}\text { Teaching Cluster I-Learner Centered Teaching } \\
\text { Learning Goals } \\
\text { - Get to know other TAs } \\
\text { - Become familiar with the overall content of the } \\
\text { cluster sessions and the How People Learn } \\
\text { framework } \\
\text { - Think about teaching and learning } \\
\text { - Who are the Vanderbilt students and why have } \\
\text { they chosen Vanderbilt? } \\
\text { - Become familiar with Vanderbilt policies } \\
\text { governing TA boundaries }\end{array}$ \\
\hline $\begin{array}{l}\text { Teaching Cluster II-Teaching at } \\
\text { Vanderbilt: Students, Policies, and } \\
\text { Resources } \\
\text { Learning Goals } \\
\text { - Become familiar with Vanderbilt } \\
\text { policies on the honor code, sexual } \\
\text { harassment, and disabilities } \\
\text { - Become more familiar with Vanderbilt } \\
\text { students }\end{array}$ & $\begin{array}{l}\text { Teaching Cluster II-Knowledge Centered } \\
\text { Teaching } \\
\text { Learning Goals } \\
\text { - Discuss how the metaphor we relate to in our } \\
\text { teaching shapes our perspective of teaching } \\
\text { - Discuss the novice to expert continuum } \\
\text { - The role of the TA in relation to students and } \\
\text { faculty } \\
\text { - Discipline-specific teaching challenges: } \\
\sim \text { Problem solving } \\
\sim \text { Running a lab } \\
\sim \text { Office hours }\end{array}$ \\
\hline $\begin{array}{l}\text { Teaching Cluster III-Giving Students } \\
\text { Feedback, Assessing Student Work, and } \\
\text { Grading } \\
\text { Learning Goals } \\
\text { - The importance of giving students } \\
\text { feedback on their work } \\
\text { - Best practices and rules to establish } \\
\text { early in the semester that can help } \\
\text { avoid future problems } \\
\text { - Grading objectively }\end{array}$ & $\begin{array}{l}\text { Teaching Cluster IlI-Assessment Centered } \\
\text { Teaching } \\
\text { Leaming Goals } \\
\text { - Introduce classroom assessment techniques } \\
\text { and discuss why they are an important tool for } \\
\text { teaching } \\
\text { - Formative assessment versus summative } \\
\text { assessment } \\
\text { - Self-reflection on different types of grading } \\
\text { - Become familiar with relevant grading policies } \\
\text { (e.g., the honor code and the Buckley } \\
\text { Amendment) } \\
\text { - Discuss best practices for facilitating lab } \\
\text { sessions }\end{array}$ \\
\hline
\end{tabular}




\section{References}

Bransford, J. D., Brown, A. L., \& Cocking, R. R. (Eds.). (2000). How people learn: Brain, mind, experience, and school (Expanded ed.). Washington, DC: National Academies Press.

Brookfield, S. D. (1995). Becoming a critically reflective teacher. San Francisco, CA: Jossey-Bass.

Curzan, A., \& Damour, L. (2000). First day to final grade: A graduate student's guide to teaching. Ann Arbor, MI: University of Michigan.

Fink, L. D. (2003). Creating significant learning experiences: An integrated approach to designing college courses. San Francisco, CA: Jossey-Bass.

Frantz, A. C., Beebe, S. A., Horvath, V. S., Canales, J., \& Swee, D. E. (2005). The roles of teaching and learning centers. In S. Chadwick-Blossey \& D. R. Robertson (Eds.), To improve the academy: Vol. 23. Resources for faculty, instructional, and organizational development (pp. 72-90). Bolton, MA: Anker.

Schön, D. A. (1983). The reflective practitioner: How professionals think in action. New York, NY: Basic Books.

Wiggins, G., \& McTighe, J. (1998). Understanding by design. Alexandria, VA: Association for Supervision and Curriculum Development. 
Appendix 16.1

\section{Fall Teaching Assistant Orientation Workshop}

\begin{tabular}{|c|c|}
\hline \multicolumn{2}{|r|}{ Tuesday, August 19, 2003} \\
\hline $8: 30-9: 00$ & Registration and Continental Breakfast \\
\hline 9:00-10:00 & $\begin{array}{l}\text { Plenary } \\
\text { - Welcome, Director, Center for Teaching } \\
\text { - Welcome, Associate Provost for Undergraduate Education } \\
\text { - Welcome, President of Graduate Student Council } \\
\text { - Center for Teaching Staff and Services } \\
\text { - A Panel of VU Undergrads Talk about Teaching } \\
\text { - F2P2: Future Faculty Preparation Program }\end{array}$ \\
\hline $10: 15-11: 30$ & $\begin{array}{l}\text { Teaching Cluster I } \\
\text { Getting Started: Expectations and Duties of TAs }\end{array}$ \\
\hline $1: 00-3: 00$ & $\begin{array}{l}\text { Teaching Cluster II } \\
\text { Teaching at Vanderbilt: Students, Policies, and Resources (Buckley } \\
\text { Amendment, Honor Code, Sexual Harassment, Evaluations, Campus } \\
\text { Resources) }\end{array}$ \\
\hline & Wednesday, August 20,2003 \\
\hline $8: 30-9: 00$ & Registration and Continental Breakfast \\
\hline $9: 00-10: 15$ & $\begin{array}{l}\text { Teaching Cluster III } \\
\text { Giving Students Feedback, Assessing Student Work, and Grading: } \\
\text { Grading with Fairness and Consistency, Avoiding Over-Grading and } \\
\text { Under-Grading, Managing Grade Complaints }\end{array}$ \\
\hline $10: 30-11: 45$ & Concurrent Sessions I \\
\hline $1: 15-2: 30$ & Concurrent Sessions II \\
\hline $2: 30-3: 00$ & Social \\
\hline
\end{tabular}




\title{
Appendix 16.2 \\ 2004 Fall Teaching Assistant Orientation Workshop
}

\author{
Tuesday, August 17, 2004 \\ 8:30-9:00 Registration and Continental Breakfast \\ 9:00-10:00 Plenary \\ - Welcome, Associate Provost for Undergraduate Education \\ - Overview, Director, Center for Teaching \\ TA Orientation Agenda \\ How People Learn Framework \\ $\sim$ Center for Teaching Staff and Services \\ - F2P2: Future Faculty Preparation Program \\ - VU Faculty Panel: How and Why Do TAs Matter?
}

10:15-11:30 Teaching Cluster I: Learner-Centered Teaching

- Who are the Vanderbilt students? What do they want and value most in a TA?

- How do you manage boundaries and authority? With your students? With your faculty?

- Relevant policies concerning sexual harassment, consensual sexual relations, and learning disabilities

- Introduction to relevant resources (e.g., the Opportunity Development Center, the Psychological and Counseling Center, and the Chaplain's Office)

1:00-3:00 Teaching Cluster Il: Knowledge-Centered Teaching

- Who are you vis-à-vis your profession?

- Office hours

- Guiding problem solving

- Teaching in the lab setting

- Leading discussions

- Teaching critical thinking skills

Wednesday, August 18, 2004

9:00-10:15 Teaching Cluster III: Assessment-Centered Teaching

- How can grading be a form of teaching?

- Criterion-referenced grading

- Time management in grading 
- Resources for grading

- Relevant policies and resources for grading, such as the honor code, the Buckley Amendment

- Grading problem sets, lab reports, papers, and essay exams

10:30-11:45 Concurrent Sessions I

1:15-2:30 Concurrent Sessions II

2:30-3:00 Social

Appendix 16.3

\section{Disciplinary Clusters in TAO 2003 and 2004}

Teaching Types

Assisting Professors I

Assisting Professors II

Engineering I

Engineering Il

Engineering III

Labs I

Labs II

Leading Discussions/

Own Course

Leading Discussions

Own Course

Own Course

\section{Disciplines}

Anthropology, Art History, Economics, Psychology, Sociology

School of Education, Graduate School of Management

Biomedical, Civil/Environmental, Management of

Technology

Electrical Engineering and Computer Science

Chemical Engineering, Material Science,

Mechanical Engineering

Biological Sciences, Physics and Astronomy, Geology,

Biomedical Science and Medicine

Chemistry, Neuroscience

Comparative Literature, History, Philosophy, Political Science

Graduate Department of Religion

English, Mathematics

Classical Studies, French/Italian, Germanic/Slavic, Spanish/Portuguese 


\section{Appendix 16.4 \\ Concurrent Session Topics in TAO 2003 and TAO 2004}

TAO 2003

Concurrent Session Topics

- Course design and syllabus construction

- Learning styles

- Writing exams and quizzes

- Managing difficult situations in class and office hours

- Time management/balancing workloads

- Technology overview

- Leading effective class discussions

- Daily lesson plans to engage students in lectures and discussions

- Effective lectures

- Engaging students in problem solving in economics, mathematics, engineering and sciences

- Working with students one-on-one in labs, office hours, and review sessions
TAO 2004

\section{Concurrent Session Topics}

- Course design and syllabus construction

- Learning styles and group dynamics in the classroom

- Writing exams and quizzes

- Managing difficult situations in class and office hours

- Time management/balancing workloads

- Establishing your teaching persona

- Engaging students/providing a positive atmosphere in the classroom

- Service-learning

- How to get the most out of your TA experience (geared toward those not excited about teaching)

- Fostering critical thinking

- Psychology of grading

- Differences in the classroom-race, class, gender 